\title{
ANALISIS MUATAN PENDIDIKAN KARAKTER DALAM BUKU TEKS KURIKULUM 2013 KELAS III SD SEMESTER 1
}

\author{
Yogi Kuncoro Adi \\ PGSD, FKIP Universitas Kuningan \\ yogi.kuncoro.adi@uniku.ac.id
}

\begin{abstract}
The aim of this study is to describe character education content of the third grade elementary school curriculum 2013 textbook semester 1. The design of this study was content analysis by qualitative approach. Subject of this study is textbook of curriculum 2013 semester 1 for the third grade of elementary school students. Object of this study is character education content. The data collected by reading and recording of unit analysis. The unit analysis were materials and evaluation that integrated the values of character education in the textbooks. The instrument used in this research was the analysis sheet based on the theories. The validity of the instrument and the data used was semantic validity and expert judgment. The reliability of the data used the stability and reproducibility. The techniques of analyzing data consisted of unitizing, sampling, recording, reducing, inferring, and narrating. The results of this study show that most of the character education value was spread into every theme, although some indicators were not found. Distribution of each character value, by disregarding any indicators, evenly on all themes. However, these findings prove that a particular character value investment is not focused as in the relevant theory.
\end{abstract}

Keywords: Content Analysis, Character Education

\section{PENDAHULUAN}

Kurikulum 2013 saat ini sedang mengalami evaluasi dan revisi. Seperti disebutkan Mendikbud (2014: 2) melalui Permendikbud nomor 160 pasal 4 bahwa sekolah di luar pilot project dapat melaksanakan KTSP paling lama sampai dengan tahun pelajaran 2019/2020. Hal ini mengartikan bahwa Kurikulum 2013 akan dilaksanakan kembali setelah dievaluasi. Begitu pula buku teks baik yang sudah diterima pihak sekolah maupun yang belum tetap akan digunakan nantinya.

Kurikulum 2013 merupakan kurikulum yang dikembangkan berbasis kompetensi. Perbedaan Kurikulum 2013 dengan kurikulum sebelumnya terlihat dari adanya penambahan kompetensi sikap spiritual dan sikap sosial, selain kompetensi keterampilan dan pengetahuan. Keempat kompetensi dalam Kurikulum 2013 dikembangkan baik dalam indikator, materi, maupun evaluasi pembelajaran. Kurikulum 2013 lebih menekankan pada pencapaian kompetensi sikap spiritual, sosial, keterampilan, dan pengetahuan secara holistik. Hal tersebut mengingat tujuan Kurikulum 2013 berkaitan dengan terciptanya warga negara yang berkarakter.

Kompetensi sikap berkaitan dengan pendidikan karakter. Setyawan \& Mustadi (2015: 108) menyatakan bahwa pendidikan karakter sebaiknya dilakukan sejak dini. Perwujudannya melalui pendidikan yang paling dasar yaitu SD. Pendidikan karakter dianggap sebagai usaha untuk menanamkan kebiasaan-kebiasaan baik sehingga siswa bersikap dan bertindak berdasarkan nilainilai yang telah menjadi kepribadiannya. Penanaman nilai karakter harus secara wajib dimuat dalam buku teks yang digunakan oleh guru dan siswa, salah satunya. 
Menurut Tarigan \& Tarigan (2009: 1314), buku teks adalah buku pelajaran dalam bidang studi tertentu yang merupakan buku standar, disusun oleh para pakar dalam bidang ilmu tersebut dan tujuan instruksional, yang dilengkapi dengan sarana pengajaran yang serasi dan mudah dipahami oleh para pemakainya di sekolah sehingga menunjang suatu program pembelajaran. Selain itu, Cunningsworth dalam Rahimpour \& Hashemi (2011: 62) juga berpendapat bahwa buku teks merupakan sumber daya yang efektif untuk belajar mandiri, menyajikan materi, ide dan kegiatan, referensi bagi siswa, silabus yang mencerminkan pembelajaran, dan dukungan untuk guru baru. Kedua pendapat di atas dapat ditarik kesimpulan bahwa buku teks memiliki peran yang sangat penting dalam proses pembelajaran, yang mana pembelajaran menjadi efektif dan efisien sehingga tujuan-pun tercapai.

Buku teks dapat dianggap sebagai alat untuk menyampaikan pesan (materi pelajaran) yang utama dari penyampai pesan (guru) ke penerima pesan (siswa). Oleh karena itu, buku teks harus disusun oleh ahlinya agar sesuai dengan kurikulum yang berlaku. Dalam hal ini, buku teks sangat mempengaruhi proses agar tercapainya tujuan pembelajaran, yang notabene pada Kurikulum 2013 berbasiskan karakter.

Perkembangan zaman selain memberikan dampak positif juga adanya dampak negatif, khususnya terhadap perkembangan karakter suatu bangsa. Akan tetapi, justru yang paling berkembang adalah sisi negatif, yaitu degradasi moral masyarakat. Menurut Zuchdi (2015: 1), degradasi moral tersebut ditandai oleh memudarnya sikap santun, ramah, serta jiwa kebhinekaan, kebersamaan, dan kegotongroyongan dalam kehidupan masyarakat Indonesia. Berdasarkan hal itu, perlu adanya program pendidikan yang dapat mewadahi berkembangnya karakter yang positif yang mengacu pada Pancasila sebagai warga yang taat negara.

Cubukcu (2012: 1527) mendefinisikan pendidikan karakter sebagai cara bagaimana mengajarkan siswa untuk memutuskan dengan baik dan bagaimana berperilaku yang sesuai. Lebih lanjut disebutkan bahwa, orang yang rendah hati, jujur, baik, setia, sabar dan bertanggung jawab diklasifikasikan sebagai orang-orang dengan karakter yang baik oleh orang lain. Pendapat ini dapat dimaknai bahwa karakter yang baik dapat ditanamkan kepada tiap siswa melalui pendidikan karakter. Hal tersebut sejalan dengan Lickona (2013: 82) yang menyatakan bahwa karakter yang baik terdiri dari mengetahui hal yang baik, menginginkan hal yang baik, dan melakukan hal yang baik (kebiasaan dalam cara berpikir, kebiasaan dalam hati, dan kebiasaan dalam tindakan). Berdasarkan pendapat tersebut, karakter yang baik harus diajarkan melalui pengetahuan moral terlebih dahulu, lalu siswa diajarkan untuk merasakan suatu moral, kemudian siswa akan melakukan tindakan mana yang dipilih setelah dipikirkan dengan matang.

Pendidikan karakter di Indonesia menjadi program yang memiliki tujuan dan fungsi yang terarah. Kemdiknas (2011: 7) dalam Panduan Pelaksanaan Pendidikan Karakter menyebutkan bahwa pendidikan karakter bertujuan mengembangkan nilainilai yang membentuk karakter bangsa yaitu Pancasila, meliputi: 1) mengembangkan potensi peserta didik agar 
menjadi manusia berhati baik, berpikiran baik, dan berprilaku baik; 2) membangun bangsa yang berkarakter Pancasila; 3) mengembangkan potensi warganegara agar memiliki sikap percaya diri, bangga pada bangsa dan negaranya serta mencintai umat manusia. Sedangkan fungsi dari pendidikan karakter adalah: 1) membangun kehidupan kebangsaan yang multikultural; 2) membangun peradaban bangsa yang cerdas, berbudaya luhur, dan mampu berkontribusi terhadap pengembangan kehidupan umat manusia; mengembangkan potensi dasar agar berhati baik, berpikiran baik, dan berperilaku baik serta keteladanan baik; 3) membangun sikap warganegara yang cinta damai, kreatif, mandiri, dan mampu hidup berdampingan dengan bangsa lain dalam suatu harmoni.

Penelitian ini dilakukan dengan meneliti buku teks terbitan Kemdikbud, maka digunakan teori Pendidikan Karakter yang relevan dengannya. Kemdikbud telah mencanangkan 18 nilai yang bersumber dari agama, Pancasila, budaya, dan tujuan pendidikan nasional. Nilai-nilai tersebut adalah religius, jujur, toleransi, disiplin, kerja keras, kreatif, mandiri, demokratis, rasa ingin tahu, semangat kebangsaan, cinta tanah air, menghargai prestasi, bersahabat/komunikatif, cinta damai, gemar membaca, peduli lingkungan, peduli sosial, dan tanggung jawab (Kemdiknas, 2011: 8). Kurikulum 2013 digadang-gadang sebagai kurikulum yang mengintegrasikan pendidikan karakter di dalamnya. Selain itu, pendidikan karakter sangat penting untuk diterapkan kepada siswa sejak usia dini.

Untuk merealisasikan karakter mulia sangat perlu dibangun budaya atau kultur yang dapat mempercepat terwujudnya karakter yang diharapkan. Kultur merupakan kebiasaan atau tradisi yang sarat dengan nilai-nilai tertentu yang tumbuh dan berkembang dalam berbagai aspek kehidupan. Kultur dapat dibentuk dan dikembangkan oleh siapa pun dan dimana pun (Zuchdi, 2015: 22). Pernyataan tersebut dapat disimpulkan bahwa, pengembangan suatu nilai karakter harus berpondasikan nilai karakter tertentu. Kesimpulan tersebut dapat dicontohkan melalui misalnya ketika guru hendak menanamkan nilai karakter disiplin pada siswa, maka guru harus sudah menanamkan nilai karakter tanggung jawab terlebih dahulu, atau kedua nilai tersebut berjalan beriringan. Pada akhirnya, pengembangan nilai karakter harus difokuskan terhadap nilai-nilai yang berkaitan, bukanlah menyebarkan ke-18 nilai secara merata sehingga tidak terfokus.

\section{METODE PENELITIAN}

Jenis penelitian ini adalah content analysis yang menggunakan pendekatan kualitatif. Peneliti dilakukan di kampus II Universitas Kuningan sebagai lokasi untuk meneliti meskipun penelitian ini tidak terbatas oleh tempat. Waktu penelitian ini dilaksanakan bulan Juni-Agustus 2016.

Subjek dan Objek Penelitian ini adalah buku teks kelas III SD semester 1 merupakan subjek dalam penelitian ini. Muatan nilai-nilai pendidikan karakter adalah objek dalam penelitian ini.

Pengumpulan data dilakukan dengan pembacaan dan pencatatan terhadap unit analisis. Unit analisis berupa materi dan evaluasi yang mengintegrasi nilai-nilai pendidikan karakter dalam buku teks. Instrumen yang digunakan adalah lembar analisis isi yang disusun berdasarkan landasan teori. 
Validitas instrumen dan data yang digunakan adalah semantic validity dan expert judgement. Reliabilitas yang digunakan adalah stability dan reproducibility. Teknik analisis data yang digunakan sesuai dengan Krippendorf (2004: 83) terdiri dari unitizing, sampling, recording, reducing, inferring, dan narrating.

\section{HASIL DAN PEMBAHASAN Hasil Penelitian}

Nilai religius pada materi pembelajaran, indikator menandakan sikap dan perilaku patuh dalam melaksanakan ajaran agama ditemukan dalam empat tema yang dianalisis. Indikator toleran terhadap pelaksanaan ibadah agama lain ditemukan 1 kali muatan di tema 3 saja. Pada evaluasi pembelajaran, indikator menandakan sikap dan perilaku patuh dalam melaksanakan ajaran agama ditemukan 1 muatan di tema 1, 6 muatan di tema 3. Indikator toleran terhadap pelaksanaan ibadah agama lain ditemukan 2 muatan di tema 1, 1 muatan di tema 3 .

Tabel 1. Jumlah Temuan Muatan Pendidikan Karakter Religius-Rasa Ingin Tahu

\begin{tabular}{|c|c|c|c|c|c|c|c|c|c|}
\hline \multirow{2}{*}{ Aspek } & \multirow{2}{*}{ Indikator Aspek } & \multicolumn{4}{|c|}{ Materi } & \multicolumn{4}{|c|}{ Evaluasi } \\
\hline & & 1 & 2 & $\mathbf{3}$ & 4 & 1 & 2 & 3 & 4 \\
\hline \multirow{3}{*}{ Religius } & Sikap dan perilaku patuh melaksanakan ajaran agama & 1 & 1 & 7 & 13 & 1 & 0 & 6 & 0 \\
\hline & Toleran terhadap pelaksanaan ibadah agama lain & 0 & 0 & 1 & 0 & 2 & 0 & 1 & 0 \\
\hline & Hidup rukun dengan pemeluk agama lain & 0 & 0 & 0 & 0 & 0 & 0 & 0 & 0 \\
\hline \multirow{3}{*}{ Jujur } & Perilaku yang selalu dapat dipercaya dalam perkataan & 0 & 0 & 0 & 2 & 0 & 1 & 3 & 3 \\
\hline & Perilaku yang selalu dapat dipercaya dalam tindakan & 0 & 0 & 0 & 0 & 0 & 0 & 0 & 0 \\
\hline & Perilaku yang selalu dapat dipercaya dalam pekerjaan & 0 & 0 & 0 & 0 & 0 & 0 & 1 & 0 \\
\hline \multirow{3}{*}{ Toleransi } & Sikap dan tindakan menghargai perbedaan agama lain & 2 & 1 & 2 & 3 & 0 & 0 & 1 & 1 \\
\hline & Sikap dan tindakan menghargai tindakan orang lain & 2 & 1 & 0 & 2 & 1 & 1 & 1 & 0 \\
\hline & $\begin{array}{l}\text { Sikap dan tindakan menghargai perbedaan suku dan } \\
\text { etnis lain }\end{array}$ & 0 & 1 & 0 & 6 & 0 & 0 & 0 & 1 \\
\hline \multirow{2}{*}{ Disiplin } & Perilaku tertib pada berbagai ketentuan dan peraturan & 4 & 4 & 0 & 11 & 3 & 3 & 1 & 4 \\
\hline & Perilaku patuh pada berbagai ketentuan dan peraturan & 6 & 10 & 0 & 2 & 11 & 16 & 0 & 4 \\
\hline \multirow{2}{*}{ Kerja Keras } & Berupaya mengatasi hambatan belajar dan tugas & 1 & 0 & 0 & 0 & 2 & 2 & 0 & 3 \\
\hline & Menyelesaikan tugas dengan sebaik-baiknya & 0 & 2 & 1 & 0 & 7 & 5 & 4 & 3 \\
\hline \multirow{2}{*}{ Kreatif } & Berpikir untuk menghasilkan ide & 0 & 2 & 1 & 4 & 2 & 0 & 0 & 2 \\
\hline & Menghasilkan cara atau hasil baru & 5 & 6 & 2 & 5 & 7 & 6 & 5 & 0 \\
\hline \multirow{2}{*}{ Mandiri } & Sikap tidak mudah tergantung pada orang lain & 1 & 3 & 0 & 0 & 1 & 3 & 0 & 3 \\
\hline & Perilaku tidak mudah tergantung pada orang lain & 0 & 1 & 0 & 0 & 6 & 2 & 0 & 1 \\
\hline \multirow{3}{*}{ Demokratis } & $\begin{array}{l}\text { Cara berpikir yang menilai sama hak dan kewajiban } \\
\text { dirinya dan orang lain }\end{array}$ & 1 & 2 & 0 & 1 & 1 & 1 & 0 & 0 \\
\hline & $\begin{array}{l}\text { Cara bersikap yang menilai sama hak dan kewajiban } \\
\text { dirinya dan orang lain }\end{array}$ & 1 & 1 & 0 & 0 & 2 & 0 & 0 & 0 \\
\hline & $\begin{array}{l}\text { Cara bertindak yang menilai sama hak dan kewajiban } \\
\text { dirinya dan orang lain }\end{array}$ & 0 & 1 & 0 & 0 & 0 & 0 & 0 & 0 \\
\hline \multirow{2}{*}{$\begin{array}{c}\text { Rasa Ingin } \\
\text { Tahu }\end{array}$} & $\begin{array}{l}\text { Sikap selalu berupaya untuk mengetahui lebih } \\
\text { mendalam dan meluas dari materi yang diamatinya }\end{array}$ & 13 & 10 & 3 & 7 & 1 & 5 & 0 & 40 \\
\hline & $\begin{array}{l}\text { Tindakan selalu berupaya untuk mengetahui lebih } \\
\text { mendalam dan meluas dari materi yang dilakukannya }\end{array}$ & 8 & 9 & 1 & 1 & 16 & 28 & 1 & 0 \\
\hline
\end{tabular}

Nilai jujur pada materi pembelajaran, indikator perilaku berupaya menjadikan dirinya sebagai orang yang selalu dapat dipercaya dalam perkataan ditemukan 2 muatan di tema 4 saja. Pada evaluasi pembelajaran, indikator perilaku berupaya menjadikan dirinya sebagai orang yang selalu dapat dipercaya dalam perkataan 
ditemukan 1 muatan di tema 2, 3 muatan di tema 3 dan 4 . Indikator perilaku berupaya menjadikan dirinya sebagai orang yang selalu dapat dipercaya dalam pekerjaan ditemukan 1 muatan di tema 3 saja.

Nilai toleransi pada materi pembelajaran, indikator sikap dan tindakan yang menghargai perbedaan agama orang lain ditemukan 2 muatan pada tema 1 dan 3, sedangkan 1 muatan ditemukan di tema 2 serta 3 muatan di tema 4. Indikator sikap dan tindakan yang menghargai tindakan orang lain ditemukan 2 muatan di tema 1 dan 4, sedangkan di tema 2 ditemukan 1 muatan. Sedangkan indikator sikap dan tindakan yang menghargai perbedaan suku dan etnis orang lain ditemukan 1 muatan di tema 2 dan 6 muatan di tema 4. Pada evaluasi pembelajaran, indikator sikap dan tindakan yang menghargai perbedaan agama orang lain ditemukan 1 muatan di tema 3 dan 4 . Indikator sikap dan tindakan yang menghargai tindakan orang lain ditemukan 1 muatan di tema 1, 2, dan 3. Sedangkan indikator sikap dan tindakan yang menghargai perbedaan suku dan etnis orang lain ditemukan 1 muatan di tema 4.

Nilai disiplin pada materi pembelajaran, indikator perilaku tertib pada berbagai ketentuan dan peraturan ditemukan 4 muatan di tema 1 dan 2, juga ditemukan 11 muatan di tema 4. Sedangkan indikator perilaku patuh ditemukan 6 muatan di tema 1, 10 muatan di tema 2 dan ditemukan pula 2 muatan di tema 4 . Pada evaluasi pembelajaran, indikator perilaku tertib pada berbagai ketentuan dan peraturan ditemukan 3 muatan di tema 1 dan 2, 1 muatan di tema 3, dan 4 muatan di tema 4. Sedangkan indikator patuh ditemukan 11 muatan di tema 1, 16 muatan di tema 2, 4 muatan di tema 4 .
Nilai kerja keras pada materi pembelajaran, indikator perilaku berupaya mengatasi berbagai hambatan belajar dan tugas ditemukan 1 muatan di tema 1 saja. Indikator menyelesaikan tugas dengan sebaik-baiknya ditemukan 1 muatan di tema 3 dan 2 muatan di tema 2. Pada evaluasi pembelajaran, indikator perilaku berupaya mengatasi berbagai hambatan belajar dan tugas ditemukan 2 muatan di tema 1 dan 2 , 3 muatan di tema 4. Indikator menyelesaikan tugas dengan sebaikbaiknya ditemukan 7 muatan di tema 1, 5 muatan di tema 2, 4 muatan di tema 3 , dan 3 muatan di tema 4 .

Nilai kreatif pada materi pembelajaran, indikator berpikir untuk menghasilkan ide ditemukan di tema 2 terdapat 2 muatan, di tema 3 terdapat 1 muatan dan di tema 4 terdapat 4 muatan. Indikator menghasilkan cara atau hasil baru ditemukan 5 muatan di tema 1 dan 4 , sedangkan di tema 2 terdapat 6 muatan serta ditemukan 2 muatan di tema 3. Pada evaluasi pembelajaran, indikator berpikir untuk menghasilkan ide ditemukan 2 muatan di tema 1 dan 4. Indikator menghasilkan cara atau hasil baru ditemukan 7 muatan di tema 1, 6 muatan di tema 2, 5 muatan di tema 3.

Nilai mandiri pada materi pembelajaran, indikator sikap tidak mudah tergantung pada orang lain dalam menyelesaikan tugas-tugas ditemukan 1 muatan di tema 1, juga terdapat 3 muatan di tema 2. Sedangkan indikator perilaku ditemukan 1 muatan di tema 2 saja. Pada evaluasi pembelajaran, indikator sikap tidak mudah tergantung pada orang lain dalam menyelesaikan tugas-tugas ditemukan 1 muatan pada tema 1 , dan 3 muatan pada tema 2, 3, dan 4. Sedangkan indikator 
perilaku ditemukan 6 muatan di tema 1, 2 muatan di tema 2, 1 muatan di tema 4 .

Nilai demokratis pada materi pembelajaran, indikator cara berpikir yang menilai sama hak dan kewajiban dirinya dan orang lain ditemukan 1 muatan di tema 1 dan 4, sedangkan di tema 2 terdapat 2 muatan. Indikator cara bersikap ditemukan 1 muatan di tema 1 dan 2 saja. Sedangkan indikator cara bertindak hanya ditemukan 1 muatan di tema 2 saja Pada evaluasi pembelajaran, indikator cara berpikir yang menilai sama hak dan kewajiban dirinya dan orang lain ditemukan 1 muatan di tema 1 dan 2 saja. Indikator cara bersikap ditemukan 2 muatan di tema 1 saja.

Nilai rasa ingin tahu pada materi pembelajaran, indikator menandakan sikap yang selalu berupaya untuk mengetahui lebih mendalam dan meluas dari materi yang diamatinya ditemukan 13 muatan di tema 1, 10 muatan di tema 2, 3 muatan di tema 3, dan ditemukan 7 muatan di tema 4 . Indikator tindakan ditemukan 8 muatan di tema 1, 9 muatan di tema 2, sedangkan di tema 3 dan 4 masing-masing ditemukan 1 muatan karakter. Pada evaluasi pembelajaran, indikator sikap ditemukan 1 muatan di tema 1, 5 muatan di tema 2, dan 40 muatan di tema 4. Indikator menandakan tindakan yang selalu berupaya untuk mengetahui lebih mendalam dan meluas dari materi yang dilakukannya ditemukan 16 muatan di tema 1, 28 muatan di tema 2 , 1 muatan di tema 3.

Nilai semangat kebangsaan pada materi pembelajaran, indikator cara berpikir yang menempatkan kepentingan bangsa dan negara di atas kepentingan diri dan kelompoknya ditemukan 1 muatan karakter di tema 1 saja. Indikator cara berwawasan hanya ditemukan 1 muatan di tema 1 saja. Pada evaluasi pembelajaran, indikator cara berpikir ditemukan 1 muatan di tema 4 saja. Indikator cara bertindak yang menempatkan kepentingan bangsa dan negara di atas kepentingan diri dan kelompoknya ditemukan 1 muatan di tema 1 saja.

Nilai cinta tanah air pada materi pembelajaran, indikator cara berpikir yang menunjukkan kesetiaan, kepedulian, dan penghargaan yang tinggi terhadap bahasa, lingkungan fisik, sosial, budaya, ekonomi, dan politik bangsa terdapat 1 muatan di tema 1, 2 muatan di tema 2, dan ditemukan 3 muatan di tema 4. Indikator cara bersikap ditemukan 4 muatan di tema 1, ditemukan 3 muatan di tema 4. Sedangkan indikator cara berbuat ditemukan masing-masing 1 muatan di tema 1, 2, dan 3. Pada evaluasi pembelajaran, indikator cara berpikir ditemukan 1 muatan di tema 1 saja. Indikator cara bersikap yang menunjukkan kesetiaan, kepedulian, dan penghargaan yang tinggi terhadap bahasa, lingkungan fisik, sosial, budaya, ekonomi, dan politik bangsa ditemukan 2 muatan di tema 3,1 muatan di tema 4. 
Tabel 2. Jumlah Temuan Muatan Pendidikan Karakter Semangat Kebangsaan-Tanggung Jawab

\begin{tabular}{|c|c|c|c|c|c|c|c|c|c|}
\hline \multirow{2}{*}{ Aspek } & \multirow{2}{*}{ Indikator Aspek } & \multicolumn{4}{|c|}{ Materi } & \multicolumn{4}{|c|}{ Evaluasi } \\
\hline & & \multirow{2}{*}{$\begin{array}{l}\mathbf{1} \\
1\end{array}$} & \multirow{2}{*}{$\begin{array}{l}2 \\
0\end{array}$} & \multirow{2}{*}{$\begin{array}{l}3 \\
0\end{array}$} & \multirow{2}{*}{$\begin{array}{l}4 \\
0\end{array}$} & \multirow{2}{*}{$\begin{array}{l}1 \\
0\end{array}$} & \multirow[t]{2}{*}{2} & \multirow[t]{2}{*}{3} & \multirow{2}{*}{$\begin{array}{l}4 \\
1\end{array}$} \\
\hline \multirow{3}{*}{$\begin{array}{l}\text { Semangat } \\
\text { Kebangsaan }\end{array}$} & $\begin{array}{l}\text { Cara berpikir yang menempatkan kepentingan bangsa } \\
\text { dan negara di atas kepentingan diri dan kelompoknya }\end{array}$ & & & & & & & & \\
\hline & $\begin{array}{l}\text { Cara bertindak yang menempatkan kepentingan bangsa } \\
\text { dan negara di atas kepentingan diri dan kelompoknya }\end{array}$ & 0 & 0 & 0 & 0 & 1 & 0 & 0 & 0 \\
\hline & $\begin{array}{l}\text { Cara berwawasan menempatkan kepentingan bangsa } \\
\text { dan negara di atas kepentingan diri dan kelompoknya. }\end{array}$ & 1 & 0 & 0 & 0 & 0 & 0 & 0 & 0 \\
\hline \multirow{3}{*}{$\begin{array}{l}\text { Cinta Tanah } \\
\quad \text { Air }\end{array}$} & $\begin{array}{l}\text { Cara berpikir yang menunjukkan kesetiaan, kepedulian, } \\
\text { dan penghargaan yang tinggi terhadap bahasa, } \\
\text { lingkungan fisik, sosial, budaya, ekonomi, dan politik } \\
\text { bangsa }\end{array}$ & 1 & 2 & 0 & 3 & 1 & 0 & 0 & 0 \\
\hline & $\begin{array}{l}\text { Cara bersikap yang menunjukkan kesetiaan, } \\
\text { kepedulian, dan penghargaan yang tinggi terhadap } \\
\text { bahasa, lingkungan fisik, sosial, budaya, ekonomi, dan } \\
\text { politik bangsa }\end{array}$ & 4 & 0 & 0 & 3 & 0 & 0 & 2 & 1 \\
\hline & $\begin{array}{l}\text { Cara berbuat yang menunjukkan kesetiaan, kepedulian, } \\
\text { dan penghargaan yang tinggi terhadap bahasa, } \\
\text { lingkungan fisik, sosial, budaya, ekonomi, dan politik } \\
\text { bangsa }\end{array}$ & 1 & 1 & 1 & 0 & 0 & 0 & 0 & 0 \\
\hline \multirow{3}{*}{$\begin{array}{c}\text { Menghargai } \\
\text { Prestasi }\end{array}$} & $\begin{array}{l}\text { Sikap dan tindakan menghasilkan ide/karya yang } \\
\text { berguna bagi masyarakat }\end{array}$ & 0 & 0 & 0 & 0 & 0 & 0 & 0 & 0 \\
\hline & Sikap dan tindakan mengakui keberhasilan orang lain & 1 & 0 & 0 & 0 & 0 & 0 & 0 & 0 \\
\hline & Menghormati keberhasilan orang lain & 1 & 0 & 0 & 0 & 0 & 0 & 0 & 0 \\
\hline \multirow{3}{*}{$\begin{array}{l}\text { Bersahabat/ } \\
\text { Komunikatif }\end{array}$} & Senang berbicara dengan orang lain & 9 & 9 & 1 & 8 & 5 & 0 & 3 & 6 \\
\hline & Senang bergaul dengan orang lain & 4 & 5 & 1 & 4 & 0 & 2 & 0 & 2 \\
\hline & Senang bekerja sama dengan orang lain & 10 & 11 & 0 & 19 & 6 & 3 & 1 & 7 \\
\hline \multirow{3}{*}{ Cinta Damai } & $\begin{array}{l}\text { Sikap yang menyebabkan orang lain merasa senang dan } \\
\text { aman atas kehadiran dirinya }\end{array}$ & 0 & 0 & 0 & 5 & 0 & 0 & 0 & 0 \\
\hline & $\begin{array}{l}\text { Perkataan yang menyebabkan orang lain merasa senang } \\
\text { dan aman atas kehadiran dirinya }\end{array}$ & 0 & 1 & 0 & 0 & 0 & 0 & 0 & 0 \\
\hline & $\begin{array}{l}\text { Tindakan yang menyebabkan orang lain merasa senang } \\
\text { dan aman atas kehadiran dirinya }\end{array}$ & 0 & 1 & 0 & 0 & 0 & 0 & 0 & 0 \\
\hline \multirow{2}{*}{$\begin{array}{c}\text { Gemar } \\
\text { Membaca }\end{array}$} & $\begin{array}{l}\text { Kebiasaan menyediakan waktu untuk membaca } \\
\text { berbagai bacaan }\end{array}$ & 1 & 11 & 4 & 13 & 0 & 0 & 0 & 0 \\
\hline & $\begin{array}{l}\text { Kesadaran menyediakan waktu untuk membaca } \\
\text { berbagai bacaan }\end{array}$ & 0 & 6 & 0 & 2 & 0 & 0 & 0 & 0 \\
\hline \multirow{2}{*}{$\begin{array}{c}\text { Peduli } \\
\text { Lingkungan }\end{array}$} & Berupaya mencegah kerusakan lingkungan alam & 8 & 0 & 1 & 8 & 6 & 0 & 0 & 4 \\
\hline & Upaya-upaya untuk memperbaiki kerusakan alam & 0 & 1 & 5 & 0 & 1 & 0 & 4 & 0 \\
\hline \multirow{2}{*}{ Peduli Sosial } & $\begin{array}{l}\text { Sikap selalu ingin memberi bantuan pada orang lain } \\
\text { dan masyarakat yang membutuhkan }\end{array}$ & 3 & 6 & 0 & 15 & 2 & 0 & 2 & 6 \\
\hline & $\begin{array}{l}\text { Tindakan selalu ingin memberi bantuan pada orang lain } \\
\text { dan masyarakat yang membutuhkan }\end{array}$ & 4 & 10 & 1 & 5 & 1 & 0 & 0 & 3 \\
\hline \multirow{5}{*}{$\begin{array}{l}\text { Tanggung } \\
\text { Jawab }\end{array}$} & Tugas dan kewajiban terhadap diri sendiri & 1 & 3 & 0 & 3 & 0 & 0 & 0 & 5 \\
\hline & Tugas dan kewajiban terhadap masyarakat & 1 & 2 & 1 & 6 & 0 & 3 & 0 & 3 \\
\hline & $\begin{array}{l}\text { Tugas dan kewajiban terhadap lingkungan (alam, sosial } \\
\text { dan budaya) }\end{array}$ & 8 & 2 & 1 & 7 & 4 & 0 & 1 & 3 \\
\hline & Tugas dan kewajiban terhadap negara & 0 & 1 & 0 & 1 & 2 & 0 & 0 & 0 \\
\hline & Tugas dan kewajiban terhadap Tuhan Yang Maha Esa & 4 & 1 & 0 & 0 & 1 & 0 & 0 & 0 \\
\hline
\end{tabular}

Nilai menghargai prestasi pada materi pembelajaran, indikator sikap dan tindakan yang mendorong dirinya untuk mengakui keberhasilan orang lain ditemukan 1 muatan karakter di tema 1 saja. Sedangkan indikator menghormati keberhasilan orang lain juga ditemukan 1 muatan karakter di tema 1 saja. Sedangkan pada evaluasi pembelajaran, ketiga indikator muatan nilai menghargai prestasi tidak ditemukan di tema manapun.

Nilai bersahabat/komunikatif pada materi pembelajaran, indikator tindakan 
yang memperlihatkan rasa senang berbicara dengan orang lain ditemukan 9 muatan di tema 1 dan 2, sedangkan di tema 3 terdapat 1 muatan serta di tema 4 terdapat 8 muatan. Indikator senang bergaul ditemukan 4 muatan di tema 1 dan 4 , sedangkan di tema 2 ditemukan 5 muatan, dan ditemukan 1 muatan di tema 3. Sedangkan indikator senang bekerja sama terdapat 10 muatan di tema 1, 11 muatan di tema 2 serta 19 muatan di tema 4. Pada evaluasi pembelajaran, indikator senang berbicara dengan orang lain ditemukan 5 muatan di tema 1, 3 muatan di tema 3, 6 muatan di tema 4. Indikator tindakan yang memperlihatkan rasa senang bergaul dengan orang lain ditemukan 2 muatan di tema 2 dan 4. Sedangkan indikator senang bekerja sama ditemukan 6 muatan di tema 1, 3 muatan di tema 2, 1 muatan di tema 3, dan 7 muatan di tema 4.

Nilai cinta damai pada materi pembelajaran, indikator sikap yang menyebabkan orang lain merasa senang dan aman atas kehadiran dirinya hanya ditemukan di tema 4 sebanyak 5 muatan. Indikator perkataan ditemukan 1 muatan di tema 2 saja. Sedangkan indikator tindakan juga ditemukan 1 muatan di tema 2 saja. Sedangkan pada evaluasi pembelajaran, ketiga indikator muatan nilai cinta damai tidak ditemukan di tema manapun.

Nilai gemar membaca pada materi pembelajaran, indikator kebiasaan menyediakan waktu untuk membaca berbagai bacaan yang memberikan kebajikan bagi dirinya ditemukan 1 muatan di tema 1, 11 muatan di tema 2, 4 muatan ditema 3 serta terdapat 13 muatan di tema 4. Indikator kesadaran di tema 2 ditemukan 6 muatan, dan 2 muatan di tema 4. Sedangkan pada evaluasi pembelajaran, indikator ketiga indikator muatan nilai gemar membaca tidak ditemukan di tema manapun.

Nilai peduli lingkungan pada materi pembelajaran, indikator sikap dan tindakan yang selalu berupaya mencegah kerusakan pada lingkungan alam di sekitarnya ditemukan 8 muatan di tema 1 dan 4 , di tema 3 terdapat 1 muatan. Indikator upayaupaya untuk memperbaiki kerusakan alam ditemukan 1 muatan di tema 2, 5 muatan di tema 3. Pada evaluasi pembelajaran, indikator sikap dan tindakan mencegah kerusakan pada lingkungan alam ditemukan 6 muatan di tema 1, 4 muatan di tema 4 . Indikator upaya-upaya untuk memperbaiki kerusakan alam ditemukan 1 muatan di tema 1, 4 muatan di tema 3 .

Nilai peduli sosial pada materi pembelajaran, indikator sikap selalu ingin memberi bantuan pada orang lain dan masyarakat yang membutuhkan terdapat 3 muatan di tema 1, 6 muatan di tema 2 dan 15 muatan di tema 4. Indikator tindakan ditemukan 4 muatan di tema 1, 10 muatan di tema 2, 1 muatan di tema 3 serta 5 muatan di tema 4. Pada evaluasi pembelajaran, indikator sikap ditemukan 2 muatan di tema 1 dan 3, 6 muatan di tema 4. Indikator tindakan selalu ingin memberi bantuan pada orang lain dan masyarakat yang membutuhkan ditemukan 1 muatan di tema 1, 3 muatan di tema 4 .

Nilai tanggung jawab pada materi pembelajaran, indikator tugas dan kewajiban terhadap diri sendiri ditemukan 1 muatan di tema 1, 3 muatan di tema 2 dan 4. Indikator tugas dan kewajiban terhadap masyarakat ditemukan 1 muatan di tema 1 dan 3 , juga terdapat 2 muatan di tema 2 serta ditemukan 6 muatan di tema 4. Pada indikator tugas dan kewajiban terhadap 
lingkungan (alam, sosial dan budaya) ditemukan 8 muatan di tema 1, 2 muatan di tema 2, 1 muatan di tema 3 serta ditemukan 7 muatan di tema 4. Indikator tugas dan kewajiban terhadap negara ditemukan 1 muatan di tema 2 dan 4. Sedangkan indikator tugas dan kewajiban terhadap Tuhan Yang Maha Esa ditemukan 4 muatan di tema 1, 1 muatan di tema 2. Pada evaluasi pembelajaran, indikator tugas dan kewajiban terhadap diri sendiri ditemukan 5 muatan di tema 4. Indikator tugas dan kewajiban terhadap masyarakat ditemukan 3 muatan di tema 2 dan 4. Pada indikator tugas dan kewajiban terhadap lingkungan (alam, sosial dan budaya) ditemukan 4 muatan di tema 1, 1 muatan di tema 3 , dan 3 muatan di tema 4. Indikator tugas dan kewajiban terhadap negara ditemukan 2 muatan di tema 1 saja. Sedangkan Indikator tugas dan kewajiban terhadap Tuhan Yang Maha Esa ditemukan 1 muatan di tema 1 saja.

\section{Pembahasan}

Karakter religius memiliki kesamaan arti dengan ketaatan beribadah. Zuchdi (2015: 26) menyatakan istilah tersebut sebagai pikiran, perkataan, dan tindakan seseorang yang diupayakan untuk selalu menjalankan ajaran agamanya. Oleh karena itu, data yang disajikan dalam deskripsi mengenai materi kegiatan siswa berdoa relevan dengan karakter religius atau taat beribadah. Akan tetapi karakter religius tidak serta merta mengenai hubungan seorang manusia dengan Tuhan-nya. Selain itu, manusia harus berhubungan baik dengan sesamanya. Hal tersebut dapat dicontohkan melalui data evaluasi ketika siswa dihadapkan suatu masalah untuk mengambil sikap tentang pelaksanaan ibadah temannya yang menandakan toleransi dalam karakter religius. Kemdiknas (2010: 9-10) menyebutkan bahwa karakter religius itu selain menandakan sikap dan perilaku yang patuh dalam melaksanakan ajaran agama yang dianutnya juga menandakan sikap toleran terhadap pelaksanaan ibadah agama lain dan hidup rukun dengan pemeluk agama lain. Akan tetapi, melalui penelitian ini, sikap yang menunjukkan terhadap hidup rukun dengan pemeluk agama lain tidak ditemukan, sehingga hal tersebut mengurangi pelaksanaan karakter religius itu sendiri.

Zuchdi (2015: 26) menyatakan bahwa kejujuran adalah sikap dan perilaku seseorang yang didasarkan pada upaya menjadikan dirinya selalu dapat dipercaya dalam perkataan dan perbuatannya. Melalui perkataan, seperti dicontohkan dalam data siswa membaca teks pertanyaan tentang beramal harian kemudian ditanya amal baik yang telah dilakukannya hari itu yang menandakan karakter jujur. Sedangkan data mengenai kejujuran dalam tindakan sangat sedikit ditemukan muatannya dalam keempat buku tema yang dianalisis. Hal yang sangat penting sebagai guru ketika memberikan contoh kepada siswanya untuk melakukan tindakan yang berlandaskan kejujuran, tidak hanya berupa perkataan. Karakter ini sangat berkaitan erat dengan nilai anti korupsi, yang notabene seharusnya secara gencar diajarkan dalam pendidikan formal. Hal tersebut sejalan dengan Syarbini \& Arbain (2014: 70) bahwa kata jujur dapat didefinisikan sebagai lurus hati, tidak berbohong, dan tidak curang. Tanpa sifat jujur, seseorang tidak akan dipercaya dalam kehidupan sosialnya. Nilai kejujuran di sekolah dapat 
diwujudkan dalam bentuk tidak melakukan kecurangan akademik.

Toleransi sebagai karakter yang berdiri sendiri adalah ketika dicontohkan melalui muatan yang menampilkan toleransi kesemua agama yang ada di Indonesia. Hal tersebut dicontohkan melalui data siswa membaca teks tentang anak yang menghormati peribadatan agama lain yang berupa sikap dan tindakan menghargai perbedaan agama orang lain. Lebih luas dari itu, Kemdiknas (2010: 9-10) menyebutkan makna toleransi sebagai sikap dan tindakan yang menghargai perbedaan agama, suku, etnis, pendapat, sikap, dan tindakan orang lain yang berbeda dari dirinya. Selain perbedaan agama, pendapat misalnya, dicontohkan melalui data siswa memahami perbedaan makanan temannya yang menandakan karakter toleransi. Melalui penanaman karakter toleransi, siswa akan memahami pelajaran di balik perbedaan. Apalagi hal tersebut didukung dengan konteks Indonesia yang merupakan negara multi agama, multi etnis, dan multi budaya.

Disiplin secara sederhana adalah mengenai ketaatan dan kepatuhan terhadap peraturan. Syarbini \& Arbain (2014: 71) menyatakan bahwa nilai kedisiplinan dapat diwujudkan antara lain dalam bentuk kemampuan mengatur waktu dengan baik, kepatuhan pada seluruh peraturan dan ketentuan yang berlaku di sekolah, mengerjakan segala sesuatunya tepat waktu, dan fokus pada pekerjaan. Salah satu yang menjadikan contoh data dari pernyataan tersebut di atas adalah ketika siswa mengurutkan alat tulis berdasarkan perintah yang ada dalam buku teks. Hal tersebut berupa tindakan yang menunjukkan perilaku tertib pada berbagai ketentuan dan peraturan. Temuan tersebut sejalan dengan Zuchdi (2015: 27) yang menyebutkan kedisiplinan sebagai sikap dan perilaku yang menunjukkan ketertiban dan kepatuhan terhadap berbagai ketentuan dan peraturan. Berdasarkan pembahasan tersebut, dapat disimpulkan bahwa Kemdikbud melalui buku teks Kurikulum 2013 ini mengharapkan nantinya setiap siswa untuk dapat menyelesaikan tugasnya baik dalam kegiatan akademik di sekolah maupun dalam kehidupan bermasyarakat. Akan tetapi, pernyataan tersebut kurang diperkuat melalui tidak selalu ditemukannya indikator karakter disiplin di setiap tema, apalagi jika difokuskan terhadap disiplin waktu.

Kemdiknas

(2010:

9-10)

mendeskripsikan karakter kerja keras sebagai perilaku yang menunjukkan upaya sungguh-sungguh dalam mengatasi berbagai hambatan belajar dan tugas, serta menyelesaikan tugas dengan sebaikbaiknya. Indikator pertama dapat disebutkan melalui temuan soal evaluasi yang meminta siswa membuat tabel berdasarkan data grafik. Siswa kelas III SD diharapkan menggunakan kemampuan analisis yang dimilikinya dalam pengerjaan soal tersebut. Hal serupa juga ditemukan melalui data siswa dalam membuat karya montase bertemakan alat transportasi. Selain mempergunakan pengetahuan dasar siswa mengenai macam-macam alat transportasi, materi pembelajaran tersebut juga berupa menyelesaikan tugas dengan sebaik-baiknya. Hal tersebut sejalan dengan pernyataan Syarbini \& Arbain (2014: 72) bahwa bekerja keras merupakan hal yang penting guna tercapainya hasil yang sesuai dengan target. Akan tetapi, bekerja keras 
akan menjadi tidak berguna jika tanpa adanya pengetahuan.

Kreativitas merupakan karakter yang sangat ditekankan dalam Kurikulum 2013. Pernyataan tersebut diperkuat dengan hampir selalu ditemukannya karakter ini di setiap tema. Pada temuan data yang telah dideskripsikan dapat dicontohkan melalui kegiatan membuat keranjang dari bahan lunak dan membuat barometer sederhana. Karakter kreatif melalui data tersebut menggunakan kegiatan yang aplikatif dalam setiap pembelajaran. Akan tetapi, kreatif tidak hanya mengenai produk baru yang dihasilkan dari tangan siswa. Karakter kreatif juga ditemukan melalui data kegiatan berpikir untuk menghasilkan cara dalam suatu hal. Seperti dijelaskan oleh Zuchdi (2015: 27) bahwa kreatif dan inovatif adalah kegiatan berpikir dan melakukan sesuatu untuk menghasilkan cara atau hasil baru dan termutakhir dari apa yang dimiliki.

Data yang telah diambil menunjukkan bahwa siswa belajar lebih mandiri untuk mencari sendiri pola dekoratif yang disukainya dari internet. Selain itu, dalam evaluasi juga disebutkan bahwa siswa diminta untuk membuat surat tentang pengalamannya selama liburan yang menandakan karakter mandiri. Hal ini sejalan dengan apa yang dikemukakan oleh Syarbini dan Arbain (2014:72), bahwa peserta didik dituntut untuk mengerjakan semua tanggung jawab dengan usahanya sendiri. Demi melihat kemandirian peserta didik, nilai kemandirian dapat diwujudkan antara lain dalam bentuk mengerjakan soal ujian secara mandiri, mengerjakan tugatugas sekolah secara mandiri, dan menyelenggarakan kegiatan siswa secara swadana.
Berdasarkan data yang telah diambil menunjukkan bahwa aspek demokratis terlihat dalam pengetahuan siswa mengenai hak-hak yang dimilikinya baik di rumah, sekolah, maupun di masyarakat. Temuan data materi disebutkan bahwa hiburan dan informasi juga merupakan hak yang dimiliki oleh siswa di rumah. Hal ini sejalan dengan Lickona (2013: 76), bahwa demokrasi pada gilirannya merupakan cara yang diketahui terbaik dalam menjamin keamanan dari hak asasi masing-masing individu (untuk memiliki rasa hormat) dan juga mengangkat makna dari kesejahteraan umum (bersikap baik dan bertanggung jawab kepada semua orang). Hal tersebut dicontohkan ketika siswa menuliskan hak dan kewajibannya baik yang sudah maupun belum diterima sehingga menunjukan bahwa mereka sedang belajar menuju pemaknaan demokratis.

Nilai rasa ingin tahu merupakan aspek yang paling dominan dalam penelitian ini. Berdasarkan data yang diambil, menunjukan bahwa siswa diharapkan mempunyai rasa ingin tahu yang tinggi. Salah satunya dengan siswa mengamati bersama gambar-gambar pola dekoratif toraja sehingga menunjukkan begitu besarnya rasa ingin tahu yang dimiliki siswa. Hal ini sejalan dengan indikator rasa ingin tahu yang dituangkan oleh Kemdiknas (2010: 10), bahwa rasa ingin tahu merupakan sikap dan tindakan yang selalu berupaya untuk mengetahui lebih mendalam dan meluas dari sesuatu yang dipelajarinya, dilihat, dan didengar. Selain itu, dengan siswa melakukan berbagai pengamatan, salah satunya terhadap jenis tanaman petani semakin mempertegas begitu besarnya rasa ingin tahu yang diharapkan dimiliki oleh siswa. 
Nilai semangat kebangsaan menurut Kemdiknas (2010:10) meliputi cara berfikir, bertindak, dan berwawasan yang menempatkan kepentingan bangsa dan negara di atas kepentingan diri dan kelompoknya. Salah satu data yang diambil, menunjukan bahwa siswa mengaplikasikan poin pertama dalam Pancasila yang menandakan karakter semangat kebangsaan dalam bentuk tindakan. Begitupun dalam evaluasi, ketika siswa melakukan pengamatan kejadian dalam musyawarah yang menunjukan karakter semangat kebangsaan dalam bentuk tindakan. Akan tetapi, hal ini kurang sesuai dengan indikator semangat kebangsaan yang dituangkan oleh Kemdiknas bahwa data menunjukan indikator tindakan saja yang ada dalam buku materi tersebut.

Karakter cinta tanah air ditunjukkan salah satunya ketika siswa membaca syair lagu tentang flora dan fauna khas Indonesia. Kemdiknas (2010: 10) menyatakan bahwa cinta tanah air merupakan cara berfikir, bersikap, dan berbuat yang menunjukkan kesetiaan, kepedulian, dan penghargaan yang tinggi terhadap bahasa, lingkungan fisik, sosial, budaya, ekonomi, dan politik bangsa. Kegiatan siswa menuliskan dongeng dengan bahasa daerahnya masingmasing juga mempertegas karakter cinta tanah air yang dimiliki oleh siswa. Namun, berdasarkan data yang diambil, terdapat satu indikator yang tidak ditemukan sama sekali dalam evaluasi. Indikatornya adalah cara berbuat yang menunjukkan kesetiaan, kepedulian, dan penghargaan yang tinggi terhadap bahasa, lingkungan fisik, sosial, budaya, ekonomi, dan politik bangsa.

Siswa sangat mengenal kata-kata prestasi dalam aktivitas di dunia pendidikan, Hal tersebut dikarenakan berkompetisi merupakan salah satu cara guru memberikan motivasi terhadap siswa. Namun dalam hal ini, siswa masih perlu banyak belajar mengenai bagaimana cara untuk menghargai prestasi seseorang. Berdasarkan data yang telah diambil, menunjukan bahwa karakter menghargai prestasi salah satunya terlihat ketika siswa membaca teks tentang saling menghargai setelah berlomba. Hal ini kurang sesuai dengan yang dituangkan oleh Kemdiknas (2010: 10), bahwa menghargai prestasi merupakan sikap dan tindakan yang mendorong dirinya untuk menghasilkan sesuatu yang berguna bagi masyarakat, dan mengakui, serta menghormati keberhasilan orang lain. Sementara dalam materi hanyalah sebatas pengetahuan saja. Selain itu dalam buku teks Kurikulum 2013 untuk kelas III SD ini hanya sedikit materi yang memungkinkan siswa untuk belajar menghargai prestasi. Bahkan dalam evaluasi tidak ditemukan sama sekali aspek tentang menghargai prestasi.

Berdasarkan data, dikatakan bahwa siswa memainkan drama bersama-sama teman sekelasnya yang menandakan karakter bersahabat/komunikatif. Temuan tersebut menunjukkan sikap siswa untuk saling bekerja sama dan bergaul dengan sesama temannya. Sebagaimana Kemdiknas (2010:10) menyebutkan bahwa bersahabat/komunikatif merupakan tindakan yang memperlihatkan rasa senang berbicara, bergaul, dan bekerja sama dengan orang lain. Kegiatan dalam pembelajaran pembelajaran saintifik mendukung sekali dengan penanaman nilai karakter komunikatif/bersahabat ini. Hal tersebut diawali dengan kegiatan mengamati sampai dengan mengomunikasikan, yang mana merupakan 
salah satu contoh kegiatan yang komunikatif/bersahabat.

Kemdiknas (2010:10) mengungkapkan bahwa karakter cinta damai adalah sikap, perkataan, dan tindakan yang menyebabkan orang lain merasa senang dan aman atas kehadiran dirinya. Berdasarkan data dalam materi pembelajaran ditemukan kegiatan masyarakat pasar, dimana ditemukan interaksi sosial yang majemuk dari tiap lapisan masyarakat. Lebih jauh di buku tersebut ditampilkan seseorang satu sama lainnya saling tegur sapa dan saling menghormati. Hal tersebut semakin jelas bahwa ada sebuah tujuan yang ingin dicapai buku tersebut terhadap karakter siswa. Akan tetapi, dalam evaluasi pembelajarannya tidak ditemukan sama sekali muatan karakter cinta damai tersebut.

Karakter gemar membaca merupakan karakter yang erat kaitannya dengan kebiasaan siswa untuk mau membaca setiap harinya. Sebagaimana Kemdiknas (2010:10) mengemukakan bahwa karakter ini merupakan kebiasaan menyediakan waktu untuk membaca berbagai bacaan yang memberikan kebajikan bagi dirinya. Sejalan dengan pengertian tersebut, buku teks dalam penelitian ini memberikan sarana untuk membiasakan siswa agar mau membaca. Jenis bacaannya pun beragam, baik itu cerita rakyat, surat, maupun cerita pengalaman dan perjalanan. Muatan teks bacaannya juga banyak mengandung nilai kebajikan untuk siswa yang membacanya. Akan tetapi, evaluasi pembelajarannya tidak ditunjukkan tentang muatan nilai karakter gemar membaca.

Karakter peduli terhadap lingkungan sangat ditekankan kepada siswa sebagai salah satu nilai baik yang harus dimilikinya. Sebagaimana Syarbini \& Arbain (2014: 74) mengatakan bahwa sebagai calon pemimpin masa depan, seorang siswa perlu memiliki rasa kepedulian terhadap lingkungannya, baik lingkungan sekolah maupun masyarakatnya. Berdasarkan data yang diperoleh, terdapat data mengenai lingkungan sekitar yang kotor beserta dampaknya, yang mana tentunya hal ini dapat dijadikan sebuah analisis bagi siswa untuk berpikir apa yang seharusnya dilakukan terhadap lingkungan dalam kehidupan nyata.

Peduli sosial membantu kita belajar dari satu sama lain. Kepedulian justru mampu menghubungkan sesama. Kemdiknas (2010:10) mengatakan bahwa karakter peduli sosial merupakan sikap dan tindakan yang selalu ingin memberi bantuan pada orang lain dan masyarakat yang membutuhkan. Nilai karakter peduli sosial ini banyak ditunjukkan dalam penelitian ini, misalnya pada materi pembelajaran yang menampilkan teks tentang anak-anak membantu orang tua. Lebih jauh lagi, nilai karakter ini bahkan dijadikan sebagai tema pembelajaran. Temuan tersebut semakin memperjelas bahwa karakter peduli sosial ini sangat penting dan ingin ditonjolkan dalam buku siswa Kurikulum 2013.

Lickona (2013: 73) menyatakan bahwa tanggung jawab berarti melaksanakan sebuah pekerjaan atau kewajiban dalam keluarga, di sekolah, maupun di tempat bekerja dengan sepenuh hati dan memberikan yang terbaik. Temuan data didapatkan ketika siswa membaca teks tentang kewajiban menjaga lingkungan sekolah. Contoh bacaan tersebut merupakan salah satu penanaman karakter tanggung jawab terhadap lingkungan, dalam hal ini lingkungan sekolah, yang dijadikan contoh 
untuk dijadikan objek tanggung jawab siswa. Data dalam penelitian ini, indikator pada karakter tanggung jawab tersebar hampir ke setiap tema.

\section{SIMPULAN}

Berdasarkan hasil penelitian dan pembahasan, dapat disajikan beberapa kesimpulan kaitannya dengan analisis muatan nilai pendidikan karakter pada buku siswa Kurikulum 2013 kelas III SD semester 1. Muatan nilai religius, jujur, dan disiplin, memiliki indikator yang tidak ditemukan pada semua tema. Karakter semangat kebangsaan, cinta tanah air, dan menghargai prestasi memiliki indikator yang tidak ditemukan dalam materi pembelajaran atau evaluasi pembelajaran. Muatan karakter cinta damai dan gemar membaca sama sekali tidak ditemukan muatannya dalam evaluasi pembelajaran. Nilai karakter toleransi, kerja keras, kreatif, mandiri, demokratis, rasa ingin tahu, bersahabat/komunikatif, peduli lingkungan, peduli sosial, dan tanggung jawab tersebar di setiap tema, serta ada indikator yang tidak ditemukan. Berdasarkan temuan dalam penelitian ini, kurang lengkapnya indikator dalam setiap aspek nilai karakter membuat penanaman setiap nilai menjadi kurang utuh. Akan tetapi, di sisi lain pengembangan suatu nilai karakter harus berpondasikan nilai karakter tertentu. Kesimpulan tersebut dapat dicontohkan melalui misalnya ketika guru hendak menanamkan nilai karakter disiplin pada siswa, maka guru harus sudah menanamkan nilai karakter tanggung jawab terlebih dahulu, atau kedua nilai tersebut berjalan beriringan. Pada akhirnya, pengembangan nilai karakter harus difokuskan terhadap nilai-nilai yang berkaitan, bukanlah menyebarkan ke-18 nilai secara merata sehingga tidak terfokus.

Berdasarkan hal tersebut, Pemerintah diharapkan memperbaiki kekurangan yang ada dari indikator-indikator aspek nilai-nilai karakter. Akan tetapi, hal tersebut juga harus memperhatikan pemfokusan pada penanaman setiap nilai karakter untuk setiap jenjang kelas. Kepada guru diharapkan ketika menggunakan buku siswa Kurikulum 2013 untuk lebih memperhatikan muatan nilai pendidikan karakter yang belum sesuai sehingga dapat memperbaikinya ketika dalam proses pembelajaran.

\section{DAFTAR PUSTAKA}

Cubukcu, Z. (2012). The effect of hidden curriculum on character education process of primary school students. Educational Sciences: Theory \& Practice, 12 (2), 1526-1534.

Kemdiknas. (2010). Pedoman sekolah: pengembangan pendidikan budaya dan karakter bangsa. Jakarta: Kemdiknas.

Kemdiknas. (2011). Panduan pelaksanaan pendidikan karakter. Jakarta: Pusat Kurikulum dan Perbukuan.

Krippendorf, K. (2004). Content analysis: an introduction to its methodology $\left(2^{\text {nd }}\right.$ ed). Thousand Oaks: Sage Publication Ltd. 
Lickona, T. (2013). Mendidik untuk membentuk karakter: bagaimana sekolah dapat memberikan pendidikan tentang sikap hormat dan bertanggung jawab. (Terjemahan Juma Abdu Wamaungo). New York: Bantam Books. (Buku asli diterbitkan tahun 1991).

Mendikbud. (2014). Peraturan menteri pendidikan dan kebudayaan nomor 160, tahun 2014, tentang pemberlakuan kurikulum tahun 2006 dan kurikulum 2013.

Rahimpour, M. \& Hashemi, R. (2011). Textbook selection and evaluation in efl context. World Journal of Education, 1, 62-68.

Setyawan, W., \& Mustadi, A. (2015). Pengembangan ssp tematik-integratif untuk membangun karakter disiplin dan kreatif siswa kelas I SD. Jurnal Prima Edukasia, 3(1), 108-119.

Syarbini, A. \& Arbain, M. (2014). Pendidikan antikorupsi: konsep, strategi, dan implementasi pendidikan antikorupsi di sekolah/madrasah. Bandung: Alfabeta.

Tarigan, H.G \& Tarigan, D. (2009). Telaah buku teks bahasa Indonesia. Bandung: Angkasa.

Zuchdi, D. (2015). Pendidikan karakter: konsep dasar dan implementasi di perguruan tinggi. Yogyakarta: UNY Press. 